Journal of Aquaculture Feed Science and Nutrition 4 (2): 27-33, 2012

ISSN: $2070-1667$

(C) Medwell Journals, 2012

\title{
Effects of Enhanced Digestive Enzymes Activity with Starch and Glycogen During Rotifer Brachionus rotundiformis Culture
}

\author{
${ }^{1} \mathrm{O}$. Nam Kwon and ${ }^{2} \mathrm{Heum}-\mathrm{Gi}$ Park \\ ${ }^{1}$ Marine Biology Center for Research and Education, Gangneung-Wonju National University, \\ 210-853 Ganuneung, Republic of Korea \\ ${ }^{2}$ Development of Marine Bioscience, Gangneung-Wonju National University, \\ 210-702 Ganuneung, Republic of Korea
}

\begin{abstract}
The purpose of this study was to identify the digestive enzymes activity of rotifer Brachionus rotundiformis enhanced by poly-saccharides added in medium and lipid classes and fatty acids changed after their enrichment. Population growth of rotifer showed significantly higher density in additive trials (starch and glycogen) than non-addition (control) $(\mathrm{p}<0.05)$. The activity assayed significantly higher amylase and Total Alkaline Protease (TAP) in additive trials than control after culture $(\mathrm{p}<0.05)$. But, TG-lipase activity was significantly higher starch trial only than control after culture and enrichment $(\mathrm{p}<0.05)$. Total lipid contents analyzed to significantly higher $9.39 \%$ in starch trial only than control after enrichment $(p<0.05)$. Free fatty acid and sterol contents showed significantly higher in additive trials than control after culture and enrichment $(\mathrm{p}<0.05)$. Unsaturated fatty acid index (UI) analyzed to significantly higher 227.6-236.6 in additive trials than 205.1 of control $(\mathrm{p}<0.05)$. DHA content was higher 15.3-16.7\% in additive trials than $13.1 \%$ of control after enrichment $(\mathrm{p}<0.05)$. Therefore, researchers saw a possibility to raise sterol content that precursor of useful ingredient as several enzyme and hormone. And researchers could be confirmed the lipid utility increased of fish larvae by raising UI by use of starch and glycogen used in the study.
\end{abstract}

Key words: Rotifer Brachionus rotundiformis, enrichment, carbohydrate addition, digestive enzymes activity, lipid classes

\section{INTRODUCTION}

Rotifer Brachionus rotundiformis was important species to live prey for early fish and crustacean larvae in the world aquaculture. The genus belonged the species are very usefully applied with suppler of essential nutrient and biotic. And several researchers have been studied for the critical period of early larvae in aspects of quantity and quality of live prey supplied for 3 decades. A reason was malnourishment of live preys but the problem could solve with enrichment by recent technique. But try for solve for the lack digestibility of early larvae have been not studied actively yet. Moyano et al. (1996) reported that ontogenetic tendency of amylase than others digestive enzymes showed similarly with early critical period of gilthead seabream. But discussion about digestibility enhancement of early larvae does not investigated because their experiment was digestive enzymatic ontogeny of gilthead seabream larvae for early adaptation of artificial micro-particle diet.

The organ for ingredient absorption of fish larvae was gradually developing after absorption of yolk sac
(Buddington, 1985; Ostaszewska, 2005) but development of digestive organ and quantity of digestive enzymes activity were a lack period than that of adult or juvenile fish (Moyano et al., 1996; Kolkovski, 2001). The period was solved soon after the action of functional stomach (Kolkovski, 2001; Chong et al., 2002). But in many fishes were maintained high alkaline protease activity for replenishing the late development of functional stomach before an open mouse (Chong et al., 2002). At see the characterization of digestive function of early larvae, digestibility replenishment supplied by exogenous diets suggested that very important for larval survival.

Therefore, the purpose of this study was to identify the digestive enzymes activity enhanced of rotifer (B. rotundiformis) by the added carbohydrates in rotifer medium and digestive enzymes activity, lipid class and fatty acid contents changed at their lipid enrichment.

\section{MATERIALS AND METHODS}

Rotifer, Brachionus rotundiformis used in effect lipid enrichment by the addition of carbohydrate during

Corresponding Author: O. Nam Kwon, 1166 Haeanro Sachunjin-Ri Sachun-Myun Gangneung City, Gangwon Provinces, Republic of Korea 
culture was to sub-culture on Laboratory of Live Food in Aquaculture, Faculty of Marine Bioscience and Technology, Kangnung National University. Researchers put the $3 \mathrm{~L}$ medium of $28^{\circ} \mathrm{C}, 1.5 \mathrm{~g} \mathrm{~L}^{-1}$ ( $5 \mathrm{~L}$ vessels) and inoculated to 1,000 rotifers $\mathrm{mL}^{-1}$ and then counted the rotifer density after $24,48 \mathrm{~h}$. The freshwater condensed Chlorella vulgaris of $2.4 \mathrm{mg} / 2,000$ rotifers was divided in equal amount and supplied twice on a day.

In the experiment of carbohydrate addition supplied to 5.0 and $7.5 \mathrm{mg} / 100,000$ rotifers the potato starch (Shohwa, Japan) and oyster glycogen (Sigma, USA) with freshwater condensed Chlorella sp. (Daesang Ltd., Korea), respectively. The effect of the carbohydrates proved in us preliminary experiments. Two rotifers enriched with Algamac $2000^{\circledR}$ (Martek, USA) during $6 \mathrm{~h}$ on room temperature $\left(20 \pm 0.5^{\circ} \mathrm{C}\right)$ after culture for $48 \mathrm{~h}$, respectively. And, the rotifers carried out the lipid enrichment with $0.3 \mathrm{~g} / 1,000,000$ rotifers. All cultures and enrichments performed in triplication. In use the rotifer after culture for $48 \mathrm{~h}$ and lipid enrichment for $6 \mathrm{~h}$, researchers investigated the effect of carbohydrate addition by analysis of some digestive enzymes activity, total protein and total lipid, lipid classes and fatty acids. Amylase, total alkaline protease and TG-lipase activities of the rotifers were assayed by Somogyi (1952) used soluble starch as substrate, Kunitz (1947) used azo casein as substrate and Schmidt et al. (1974) used olive oil as substrate. Total protein calculated to use the total amino acid quantity after assay the protein bound amino acids by amino acid analyzer (L-8800, Hitachi, Japan).

Lipid classes, fatty acids and total lipid content assayed as the follows. Brief, lipid classes were determined using Thin Layer Chromatography with Flame Ionization Detected (TLC/FID) (MARK Vnew, Iatron, Japan) as described by Parrish (1987). Extracts were spotted on silica gel coated chromarods and a three stage development system was used to separate lipid classes. The first separation consisted of $20 \mathrm{~min}$ developments in 99:1:0.05 hexane/diethyl ether/formic acid. The second separation consisted of a $40 \mathrm{~mm}$ development in 80:20:1 hexane/diethyl ether/formic acid. The last separation consisted of $15 \mathrm{~mm}$ developments in 100\% acetone followed by $10 \mathrm{~mm}$ developments in 5:4:1 chloroform/methanol/water extracted chloroform. After each separation, the rods were scanned and the three chromatograms were dotted using recorder (Iatro-coder, Iatron, Japan). The signal detected in micro volts was quantified using lipid standards (sterol, ST, cholesterol; steryl esters, SE, cholesteryl palmitate; triacylglycerol, $\mathrm{TAG}$, tripalmitin; hydrocarbons, $\mathrm{HC}$, nonadecane; methyl ketones, KET, 3-hexadecane; alcohols, ALC, 1-hexadecanol; free fatty acid, FFA, palmitic acid; phospholipids, PL, DL- $\alpha$-phosphatidylcholine dipalmitoyl and acetone mobile polae lipids, AMPL 1monopalmitoyl-rac-glycerol) purchased from Sigma. And the total lipid was measured by the sum of each class quantity calculated by the 9th standard reagent. Fatty Acid Methyl Esters (FAME) were prepared by trans-esterification with $10 \% \mathrm{BF} 3-\mathrm{MeOH}$ at $85^{\circ} \mathrm{C}$ for $1 \mathrm{~h}$ (Morrison and Smith, 1964; Budge, 1999). A gas chromatography (HP 6890N, Algilent, USA) equipped with an Auto-Sampler (Algilent, USA) was used for fatty acid analysis. A DB- 225 column ( $20 \mathrm{~m}$ long, $0.1 \mathrm{~mm}$ i.d., $0.1 \mu \mathrm{m}$ film thickness, Supelco, USA) was used for separations. Helium was used as the carrier gas and the flow rate was set at $70 \mathrm{~mL} \mathrm{~min}^{-1}$. The column temperature profile was same as the follows; standing at $50^{\circ} \mathrm{C}$ for $1 \mathrm{~min}$, increase to $10^{\circ} \mathrm{C} \mathrm{min}^{-1}$ from $50-250^{\circ} \mathrm{C}$ and then hold at $250^{\circ} \mathrm{C}$ for $30 \mathrm{~min}$. Temperature of injector was $250^{\circ} \mathrm{C}$ and was held at $250^{\circ} \mathrm{C}$. Fatty acid peaks were integrated using the GC. A gas chromatography software and identification was made with reference to known standards (PUFA 37 component FAME mix, Supelco, USA). All analyses performed in triplicates of every trial.

The data were subjected to one-way ANOVA to test the growth factor, digestive enzyme, total lipid, lipid classes and fatty acid of rotifer. If significant $(p<0.05)$ differences were found, Duncan's multiple range test (Duncan, 1955) was used to rank the groups. The data are presented as mean \pm SD of three replicates. All statistical analyses were carried out by using the SPSS program Version 10.0.7 (SPSS Inc., 2000, Michigan Avenue, Chicago, Illinois, USA).

\section{RESULTS AND DISCUSSION}

Population growth of rotifer Brachionus rotundiformis cultured with starch and glycogen and enriched were shown in Fig. 1. In $24 \mathrm{~h}$ after inoculation, number of rotifer of carbohydrate additive trials were significantly high to $2,187-2,280$ rotifers $\mathrm{mL}^{-1}$ than 1,220 rotifer $\mathrm{mL}^{-1}$ of control $(\mathrm{p}<0.05)$ and number of rotifer after $48 \mathrm{~h}$ was the significantly highest 7,027 rotifer $\mathrm{mL}^{-1}$ in glycogen trial than 5,200 rotifers $\mathrm{mL}^{-1}$ of control $(\mathrm{p}<0.05)$. Number of rotifers of all trials decreased to $720-880$ rotifers $\mathrm{mL}^{-1}$ than 1,000 rotifers $\mathrm{mL}^{-1}$ of initial after lipid enrichment for $6 \mathrm{~h}$ at room temperature after $48 \mathrm{~h}$ culturing and all trials showed not the significant difference $(p>0.05)$. Activities of digestive enzymes of rotifer cultured for $48 \mathrm{~h}$ and enriched for $6 \mathrm{~h}$ were shown in Fig. 2. Amylase showed the significantly lowest activity as $3.65 \mathrm{U} \mathrm{mg} \mathrm{protein}{ }^{-1}$ in control and starch trial assayed with the significantly highest $12.39 \mathrm{U} \mathrm{mg} \mathrm{protein}^{-1}$ after culturing $(\mathrm{p}<0.05)$. TAP activity showed the significantly 
additive trials than that of control after lipid enrichment but values of TAP and TG-lipase activities differed not among with all trials $(\mathrm{p}>0.05)$.

Protein content, lipid content, lipid classes and fatty acids were shown in Table 1 . Protein content showed with the significantly highest as $65.3 \%$ in starch trial after with the $2.65 \mathrm{U} \mathrm{mg}$ protein ${ }^{-1}$ in control and the significantly highest activity showed with $3.08 \mathrm{U} \mathrm{mg}$ protein $^{-1}$ in
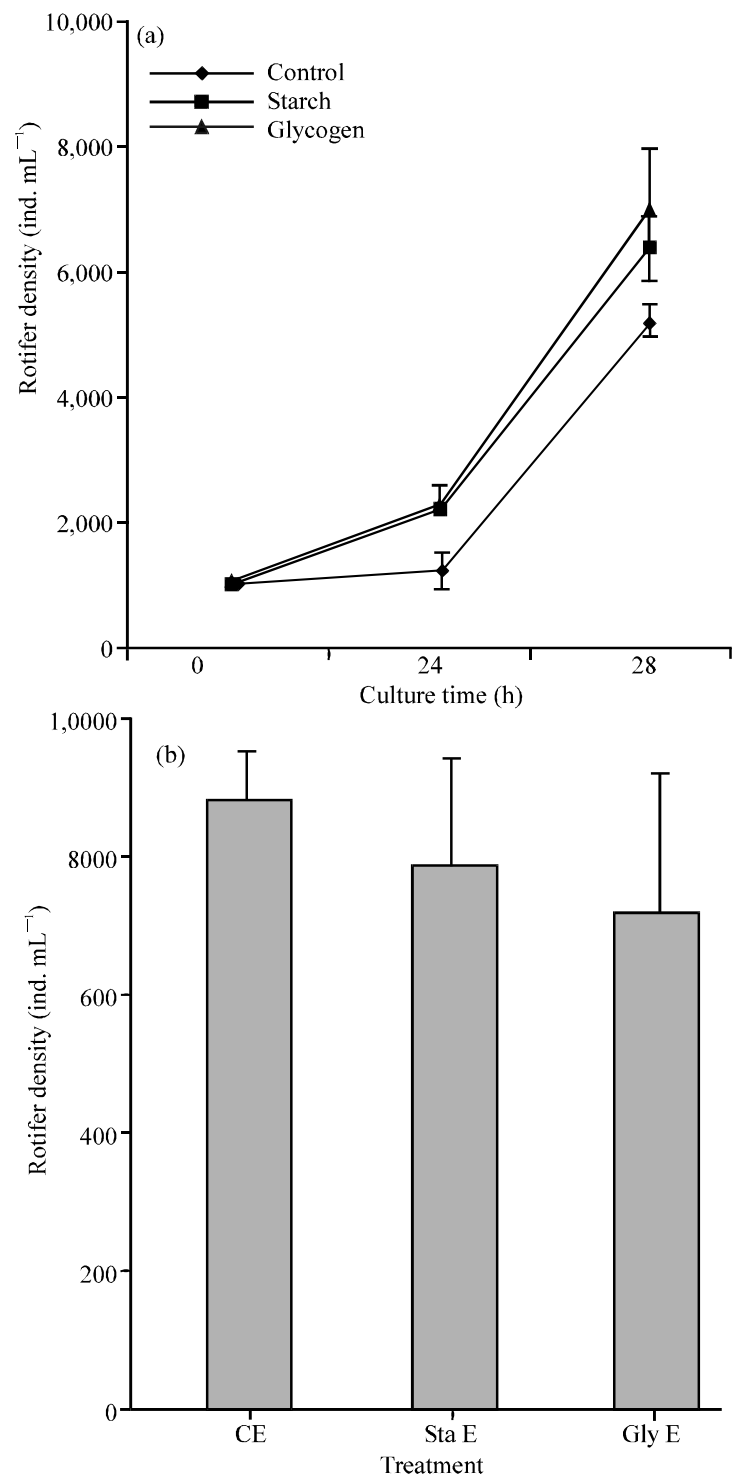

Fig. 1: The growth (mean $\pm \mathrm{SD}$ ) of rotifers, Brachionus rotundiformis that were fed freshwater condensed Chlorella sp., with/without supplementations (Sta, starch and Gly, glycogen) a) before; b) after lipid enrichment. StaE and GlyE are the rotifers that were lipid enriched with Algamac 2000 ${ }^{\circledR}$. CE indicated the commonly enriched rotifer after lowest culturing with non-adding of two poly-saccharides glycogen trial $(\mathrm{p}<0.05)$. TG-lipase assayed the significantly highest activity as $0.109 \mathrm{mU} \mathrm{mg} \mathrm{protein}^{-1}$ in starch trial than these of control and glycogen trial $(p<0.05)$. Digestive enzymes activity showed that amylase activity showed significantly higher in carbohydrate culturing and lipid enriching. Lipid content were significantly higher value to 10.57 and $10.36 \%$ in starch and glycogen trial than $7.93 \%$ of control but starch trial showed high lipid content than others trials after lipid enrichment for $6 \mathrm{~h}(\mathrm{p}<0.05)$.

In lipid classes, the TG content were assayed higher in control than that of other trials after $48 \mathrm{~h}$ culture $(\mathrm{p}<0.05)$, FFA and ST contents showed significantly higher to $14.5-14.8$ and $9.3-9.9 \%$ in starch and glycogen trials than 12.0 and $6.0 \%$ of control, respectively $(\mathrm{p}<0.05)$. And ST was assayed significantly higher also in starch and glycogen trials than that of control after enrichment in $20^{\circ} \mathrm{C}(\mathrm{p}<0.05)$. PL content were not significantly differed with 62.0-64.9\% after culturing for $48 \mathrm{~h}$ in all trials $(\mathrm{p}>0.05)$. But after lipid enrichment, PLs of control and starch trial were significantly higher to $60.3-63.5 \%$ than that of

Table 1: Protein, total lipid, lipid classes and fatty acid contents (mean \pm SD) of rotifers, Brachionus rotundiformis that were fed freshwater condensed Chlorella sp., with/without additives (Sta, starch and Gly, glycogen) before/after lipid enrichment. StaE and GlyE are the rotifers that were lipid enriched with Algamac $2000^{\circ}$

\begin{tabular}{|c|c|c|c|}
\hline Contents & Control & Starch & Glycogen \\
\hline \multicolumn{4}{|l|}{ After culturing during $48 \mathrm{~h}$} \\
\hline Protein contents $(\%, \mathrm{DW})$ & $57.6 \pm 0.43^{\mathrm{a}}$ & $65.3 \pm 0.83^{b}$ & $57.3 \pm 0.54^{\mathrm{a}}$ \\
\hline Total lipid (mg g DW-1) & $84.4 \pm 6.91^{b}$ & $79.8 \pm 2.22^{b}$ & $63.2 \pm 0.68^{a}$ \\
\hline \multicolumn{4}{|l|}{ Lipid classes (\% of total lipids) } \\
\hline Triacylglycerol (TG) & $8.0 \pm 0.36^{c}$ & $6.3 \pm 0.46^{b}$ & $4.6 \pm 0.81^{a}$ \\
\hline Free Fatty Acid (FFA) & $12.0 \pm 0.82^{\mathrm{a}}$ & $14.8 \pm 0.84^{b}$ & $14.5 \pm 0.79^{b}$ \\
\hline Sterol (ST) & $6.0 \pm 1.06^{\mathrm{a}}$ & $9.3 \pm 0.42^{b}$ & $9.9 \pm 1.19^{b}$ \\
\hline Phospholipid (PL) & $64.9 \pm 1.74$ & $62.0 \pm 2.37$ & $62.3 \pm 1.54$ \\
\hline \multicolumn{4}{|c|}{ Fatty acids (\% of total fatty acids) } \\
\hline Arachidonic acid (ARA) & $1.0 \pm 0.06$ & $1.1 \pm 0.14$ & $1.0 \pm 0.09$ \\
\hline Eicosapentaenoic acid (EPA) & $0.3 \pm 0.06^{b}$ & $0.1 \pm 0.01^{\mathrm{a}}$ & $0.3 \pm 0.05^{b}$ \\
\hline Docosahexaenoic acid (DHA) & - & - & - \\
\hline $\begin{array}{l}\text { High unsaturated fatty } \\
\text { acid (HUFA) }\end{array}$ & $73.0 \pm 2.32$ & $73.7 \pm 0.28$ & $74.2 \pm 1.58$ \\
\hline Fatty acid unsaturation ratio (UI) & $157.7 \pm 5.14$ & $158.7 \pm 0.12$ & $160.2 \pm 2.78$ \\
\hline Contents & $\mathrm{CE}$ & $\mathrm{StaE}$ & GlyE \\
\hline \multicolumn{4}{|c|}{ After enrichment of lipid after culturing during $48 \mathrm{~h}$} \\
\hline Protein contents $(\%, \mathrm{DW})$ & $46.9 \pm 0.05^{b}$ & $44.2 \pm 0.09^{\mathrm{a}}$ & $47.6 \pm 0.36^{c}$ \\
\hline Total lipid (mg g DW ${ }^{-1}$ ) & $80.0 \pm 2.95^{\mathrm{a}}$ & $93.9 \pm 5.93^{b}$ & $82.3 \pm 4.78^{a}$ \\
\hline \multicolumn{4}{|l|}{ Lipid classes (\% of total lipids) } \\
\hline TG & $21.6 \pm 3.02^{\mathrm{a}}$ & $18.3 \pm 0.78^{a}$ & $26.0 \pm 2.26$ \\
\hline FFA & $8.6 \pm 0.93$ & 76. \pm 0.46 & $7.9 \pm 0.59$ \\
\hline ST & $3.9 \pm 1.29^{\mathrm{a}}$ & $7.0 \pm 1.04^{b}$ & $6.1 \pm 0.5^{b}$ \\
\hline PL & $60.3 \pm 2.2^{b}$ & $63.5 \pm 2.2^{b}$ & $53.5 \pm 1.5$ \\
\hline \multicolumn{4}{|c|}{ Fatty acid (\% of total fatty acids) } \\
\hline ARA & $1.2 \pm 0.21$ & $1.3 \pm 0.15$ & $1.2 \pm 0.19$ \\
\hline EPA & $1.1 \pm 0.18^{\mathrm{a}}$ & $2.2 \pm 0.18^{b}$ & $2.0 \pm 0.35^{b}$ \\
\hline DHA & $13.1 \pm 0.79^{\mathrm{a}}$ & $15.3 \pm 1.03^{b}$ & $16.7 \pm 1.25^{b}$ \\
\hline HUFA & $67.5 \pm 3.42^{\mathrm{a}}$ & $72.8 \pm 2.32^{b}$ & $75.1 \pm 1.24^{b}$ \\
\hline $\mathrm{DHA} / \mathrm{EPA}$ & $12.5 \pm 1.75^{b}$ & $7.1 \pm 0.91^{\mathrm{a}}$ & $8.5 \pm 1.61^{\mathrm{a}}$ \\
\hline EPA/ARA & $0.9 \pm 0.21^{\mathrm{a}}$ & $1.7 \pm 0.35^{b}$ & $1.6 \pm 0.04^{b}$ \\
\hline UI & $205.1 \pm 9.77^{\mathrm{a}}$ & $227.6 \pm 8.98^{b}$ & $236.6 \pm 6.27^{b}$ \\
\hline
\end{tabular}

Same superscript on each row of each parameter was not the significant difference, respectively 

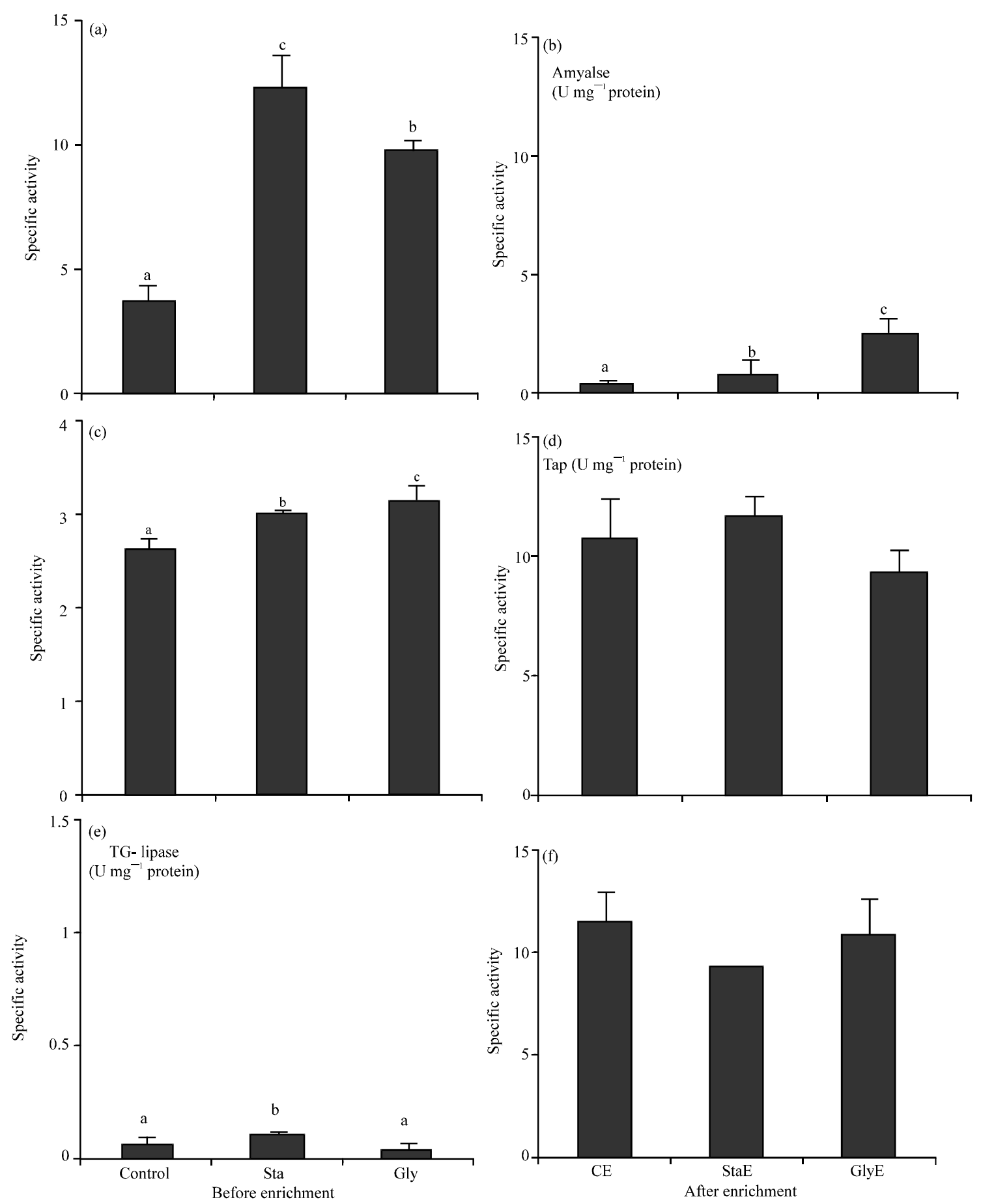

Fig. 2: Specific activities (mean $\pm \mathrm{SD}$ ) of $\alpha$-amylase, Total Alkaline Protease (TAP) and Triglyceride (TG)-lipase of rotifers Brachionus rotundiformis that were fed with freshwater condensed Chlorella sp., with/without supplementations (Sta, starch and gly, glycogen) before/after lipid enrichment. StaE and GlyE are the rotifers that were lipid enriched with Algamac $2000^{\boxplus}$. Bars with the same letters are not significantly different $(\mathrm{p}<0.05)$

glycogen trial $(\mathrm{p}<0.05)$. Unsaturated Index (UI) of fatty acid were not significantly differed to $157.7-160.2$ in all trials after culturing for $48 \mathrm{~h}(\mathrm{p}>0.05)$ but in index was significantly higher to 227.6 and 236.6 (starch and 
glycogen trial, respectively) than 205.1 of control after lipid enrichment $(p<0.05)$. DHA content was not detected in all trials cultured for $48 \mathrm{~h}$ but it showed higher value in starch and glycogen trials (15.3 and 16.7\%, respectively) than $13.1 \%$ of control after lipid enrichment $(\mathrm{p}<0.05)$. And DHA/EPA ratio showed the significantly highest value as 12.5 in control than 7.1-8.5 of others trial $(\mathrm{p}<0.05)$.

Starch and glycogen were polymer, plant and animal store carbohydrate, respectively and it hydrolyzed to maltose and glucose by the $\alpha$-amylase in animal digestive organs. The glucose absorbed in body elevated the lipid contents as TG or ST in blood and known to promote the secretion of insulin and growth hormone in blood (Werbin et al., 1960).

Promotion of lipids content: Because TG-lipase hydrolyzed TG was plenty than PLA (mainly PLA2) hydrolyzed the phospholipids in fish larvae and TG was useful than PL as early supplier of High Unsaturated Fatty Acids (HUFA) for fish larvae. But because HUFAs as DHA and EPA were bound in abundance in PL than TG, TG and PL with suppliers of early HUFAs were important requisite nutrients to larvae. And glucose hydrolyzed from starch and glycogen was basic organic matter synthesized several matters and trials added starch and glycogen were useful for an organic matters and a secretion of several useful hormone. Because lipids (mainly cholesterol) induced by ingestion of sugar were a precursor on hormones metabolism and glucose which become basic organic matter in TCA cycle, the carbohydrate addition trials suggested to benefit for organic matter synthesis and several useful hormone for somatic growth. But this theme might be needed more researches and experiments by in vivo. But accumulation of animal sterol (cholesterol) could express to show exactly higher additive trial (starch and glycogen) than that of the control by indirect expression. The ST was a precursor of digestive enzyme and several hormones and was using to synthesis of digestive enzymes precursor in a pancreas (Rosenblum et al., 1993; Hofken et al., 1998) and a sterol conveyed to organs produced several hormone syntheses the estradiol and testosterone as steroid hormone (sex-hormone) (Werbin et al., 1960). And, a sterol was not only adjust of environmental tolerance by synthesis to cortisol called to stress hormone but also give aid to control of blood pressure and blood sugar (Soffer et al., 1961). The researches related with effect on early larvae became to increasing of sterol in rotifer synthesized from glucose as the study have not carried out yet.

But Brown and Kim (1995) and Kim and Brown (1997) reported a results that larval digestive enzymes activity, survival and somatic growth was increased by addition of cortisol, steroid hormone in culture medium. If sees such result, studies about exogenous sterols were suggested to need certainly for a larval growth and health. Also, FFA content showed higher values in carbohydrate additive trials and this is suggested to need the discussion about nutrient absorbility in intestine of larvae.

Increasing of digestive enzymes activity: The enhancements of rotifer population growth by add the carbohydrate was able to confirm. And, researchers had known not only enhancement of rotifer population growth but also increasing of carbohydrate, protein and lipid hydrolysis enzymes. These enzymes take the same tendency with synthesis of sterol by glucose expressed on front and the STs increased can enough express the process making to digestive enzyme precursor in pancreas. However, despite rotifer is animal, their activities were assayed higher in starch as vegetable store carbohydrate than glycogen as animal store carbohydrate and this could express to their food habit as herbivore. Because glucoses hydrolyzed by carbohydratase (i.e., glucosidase) same in starch and glycogen, their difference suggested what type bound of glucose of two polysaccharides differ with between vegetable and animal store carbohydrates. Accurately dose not become the explanation because quantity of glucose and maltose hydrolyzed from two polysaccharides and quantitative changes of maltase induced by maltose hydrolyzed by amylase were not assayed in this study. However if it see, the procedure made to digestive enzyme and hormone after a glucose becomes sterol in TCA cycle (AMPL signaling) (Russek, 1963), activities of others digestive enzymes than 3 sorts digestive enzymes assayed in this study would increase. However if it see the increasing tendency of the digestive enzyme activities after $48 \mathrm{~h}$ culture, increasing of TAP activity as protein hydrolysis enzyme was lower activity than different digestive enzymes in starch trial. Characterization of digestive enzymes takes the substrate peculiarity increased by increase of quantity of substrates. If explains with substrate peculiarity of the same digestive enzymes, increase of crude proximate by single material as glucose could predict the increase of store carbohydrates and lipids. And then, activities of amylase and TG-lipase hydrolyzed the two components (carbohydrates and lipids) suggested that would show higher activities in others trials than control. But because protein is also synthesized, only would be quantitative differences in TCA-cycle, increasing of all components would be able to expect (Blank and Sauer, 2004). The reason that all trials assayed to similar nutrient components could be not 
much changed in a creature. And then overrun nutrients would consumed as propagation (Blank and Sauer, 2004). Thus also in this study, the population growth fasted by the reason.

Tendency increased of growth hormone: The polymers as starch and glycogen were hydrolyzed to glucose by the amylase and maltase in digestive organ. The glucose as finally hydrolyzing product did the inhibitive action in whole digestive functions at excess supplying in aspect of digestive enzymes (Epps and Gale, 1942; Monod, 1947). However, the small glucose enhanced the digestive enzymes activity in the preliminary experiment of the study, oversupplied glucose revealed to take the much inhibiting function of digestive enzymes as glucose effect. And insulin quantity in blood increase to body defensive mechanism due to the reducing the blood sugar levels with supplement of glucose in the aspect (Ariznavaeerta et al., 2003). And then growth hormone was increased a TG-lipase activity to reduce the utility of glucose (Davidsom, 1987). So, growth hormone increased was known to contribute directly or indirectly several organs by increase of cell number (hyperplasia) than size of cells (hypertrophy) at several organs (Ohlsson et al., 1998). And, the glucose was related with increasing insulin and decreasing glucagon for adjustment of a blood sugar lever, especially (Hemre et al., 2002). With this mechanism of glucose effect on zoo plankton was not become known, like this explanation was possible.

\section{CONCLUSION}

As from the results, starch and glycogen as glucose polymer showed the several effects in animal body as rotifer in this study. These components were increased the several digestive enzymes activity due to the ST increased and precursor of a digestive enzymes and hormones. Also with use of these carbohydrates, researchers could be enhanced to increase the TG-lipase activity for use of lipid and could be increased the contents of EPA, DHA needed to the larvae after lipid enrichment. In specially, use of the carbohydrates showed the effect induced the UI of fatty acid. And then the effect of carbohydrate thought to the interesting study for fish larvae.

\section{REFERENCES}

Ariznavaeerta, C., C. Castillo, G. Segovia, F. Mora and I. Azcortia, 2003. Growth hormone and aging. HOMO, 54: 132-141.
Blank, L.M. and U. Sauer, 2004. TCA cycle activity in Saccharomyces cerevisiae is a function of the environmentally determined specific growth and glucose uptake rates. Microbiology, 150: 1085-1093.

Brown, C.L. and B.G. Kim, 1995. Combined application of cortisol and triiodothyronine in the culture of larval marine finfish. Aquacult., 135: 79-86.

Buddington, R.K., 1985. Digestive secretions of lake sturgeon (Acipenser fulvescens) during early development. J. Fish. Biol., 26: 715-723.

Budge, S.M., 1999. Fatty acid biomarkers in a cold water marine environment. Ph.D., Thesis, Memorial University of Newfoundland, Canada.

Chong, A., R. Hashim, L.C. Lee and A bin Ali, 2002. Caharacterization of protease activity in developing discus Symphysodon aequifasciata larva. Aquacult. Res., 33: 663-672.

Davidsom, M.B., 1987. Effect of growth hormone on carbohydrate and lipid metabolism. Endocri. Rev., 8: 115-131.

Duncan, D.B., 1955. Multiple-range and multiple F-tests. Biometrics, 11: 1-42.

Epps, H.M.R. and E.F. Gale, 1942. The influence of the presence of glucose during growth on the enzymic activities of Escherichia coli: Comparison of the effect with that produced by fermentation acids. Biochem. J., 36: 619-623.

Hemre, G.I., T.P. Hommsen and A. Krogdahl, 2002. Carbohydrate in fish nutrition: Effects on growth, glucose metabolism and hepatic enzymes. Aquacult. Nut., 8: 175-194.

Hofken, T., D. Linder, R. Kleene, B. Goke and A.C.C. Wagner, 1998. Membrane dipeptides and glutathione are major components of pig pancreatic zymogen granules. Exp. Cell. Res., 244: 481-490.

Kim, B.G. and C.L. Brown, 1997. Interaction of cortisol and thyroid hormone in the larval development of the pacific threadfin. Am. Zool., 37: 470-481.

Kolkovski, S., 2001. Digestive enzymes in fish larvae and juveniles-implications and application to formulated diets. Aquaculture, 200: 181-201.

Kunitz, M., 1947. Crystalline soybean trypsin inhibitor II. General properties. J. Gen. Physiol., 30: 291-310.

Monod, J., 1947. The phenomenon of enzymatic adaptation. Growth, 11: 223-289.

Morrison, W.R. and L.M. Smith, 1964. Preparation of fatty acid methyl esters and dimethylacetals from lipids with boron trifluoride-methanol. J. Lipid Res., 5: 600-608.

Moyano, F.J., M. Diaz, F.J. Alarcon and M.C. Sarasquete, 1996. Characterisation of digestive enzyme activity during larval development of gilthead seabream Sparus aurata. Fish Physiol. Biochem., 15: 121-130. 
Ohlsson, C., B. Bengtsson, O.G.P. Isaksson, T.S. Andreassen and M.C. Slootweg, 1998. Gworth hormone and bone. Endocri. Rev., 19: 55-79.

Ostaszewska, T., 2005. Developmental changes of digestive system structures in pike-perch Sander lucioperca L. Electronic J. Ichthyol., 2: 65-78.

Parrish, C.C., 1987. Separation of aquatic lipid classes by Chromarod thin-layer chromatography with measurement by Iatroscan flame ionization detection. Can. J. Fish. Aquatic Sci., 44: 722-731.

Rosenblum, E.R., R.E. Sauber, D.H. Thiel, I.M. Campbell and H.S. Gavaler, 1993. Assessment of the oestrogenic activity of phytosisterorogens isolated from bourbon beer. Alcoholism: Clin. Exp. Res., 17: $1207-1209$.
Russek, M., 1963. Participation of hepatic glucoreceptors in the control of intake of food. Nat., 197: 79-80.

Schmidt, F.H., H. Stork and K. Dahl, 1974. Lipase, Photometric Assay. In: Methods of Enzymatic Analysis, Bergmeyer, H.U., (Ed.). Vol. 2, Academic Press, New York, pp: 819-823.

Soffer, L.J., A. Iannaccone and J.L. Gabrilove, 1961. Cushing's syndrome: A study of fifty patients. Am. J. Med., 30: 129-146.

Somogyi, M., 1952. Notes on sugar determination. J. Biol. Chem., 195: 19-23.

Werbin, H., I.L. Chaik off and E.E. Jones, 1960. The metabolism of H3-â-sitosterol in the guinea pig: Its conversion to urinary cortisol. J. Biol. Chem., 235: 1629-1633. 